\title{
52. 人工心臟植え込み後の心房圧測定方法
}

\section{目 的}

完全置換型人工心臟植え込み実験において, われわれは心房圧を測定するために，ダクロン グラフト製の心房カフにチューブを取り付け直 接測定を行ってきた。しかし，長期間の測定を 行う場合, 抗凝固剂を使用しても，チューブ内 に血栓形成が起こり，測定に大きな支障をきた してきた，最近，われわれは西独 BMT 社製の BMT 990 を入手したので，その使用経験を報 告する.（写真 1 )

\section{構 造}

BMT 990 は vacuum pump 1 台, filling pump 2 台抢よび, control unit 2 台より成 り, air line の圧調整を行う. filling pumpは 内径 $5 \mathrm{~mm}$ 長さ100mmのsilicon tube を rollor で10段階に分けてしごき，送り出す空気量を調 整する. vacuum pump は filling pump から 送られてくる空気量が常に capsule 内に同じ圧 をかけるようにするため capsule 内に陰圧をか け，完全に空気を抜き取る働きをする．control unit は, timing pulse を各々の pumpに出し て制御するためのものである（写真 2 )。これ に圧測定のための air capsule を接続, トラン スデューサを介して，ポリグラフを介して記録 を行う。

この装置によって, 血液の圧変化を空気圧の 変化に変えて, 直接心房圧を計らず空気圧の変 化を測定する，長時間測定していると，チュー ブ内の空気量が低下するために， BMT 990 に

* 広島大学医学部第 1 外科・人工心臟実験施設

$\begin{array}{lll}\text { 田上重喜* } & \text { 前田佳之* } & \text { 磯野基 明* } \\ \text { 村下純二* } & \text { 松村 誠* 岩 宮 博* } \\ \text { 大坪厚美* } & \text { 三好信和* } & \text { 中垣 満* } \\ \text { 田口一美* } & & \end{array}$

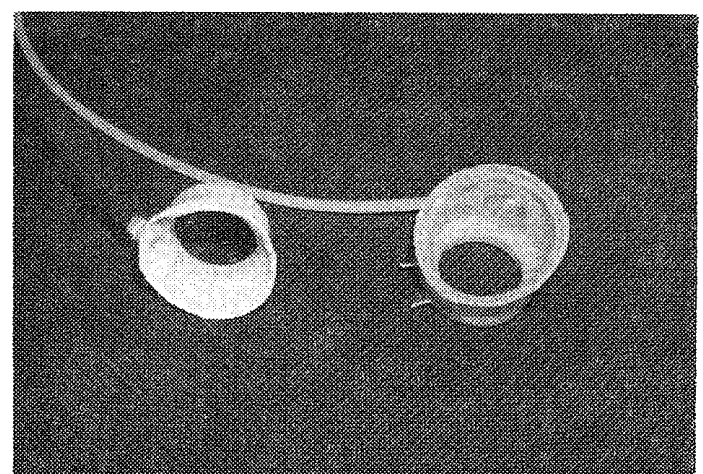

写真1 左 : 現在使用中の圧モニタ付心房カフ 右：西独自由ペルリン大学で使用中の 心房カフ

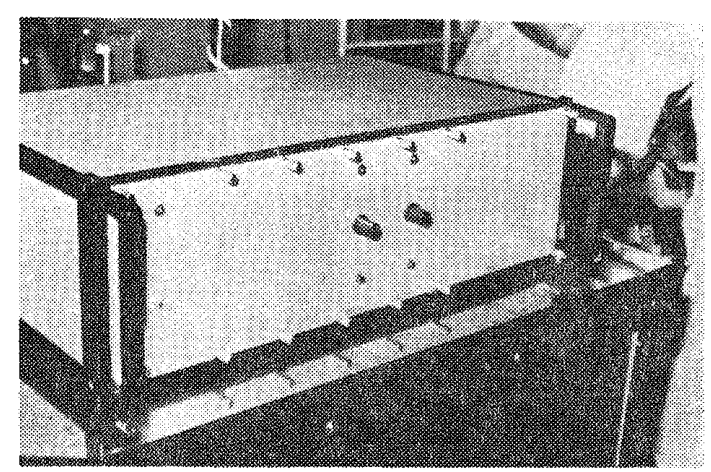

写真 2 BMT 990の外観

よってチューブ内の空気量を 7 分毎に check 乙, 必要な圧較正を自動的に行う。

air capsule は， $16 \mathrm{~mm} \times 13 \mathrm{~mm}$ の棈円形金属 の皿形に silicon，または avcothane を使用し て diaphragm を作り，皿型に固定する。diaphragm の厚みは0. 15mm, capsule volume は $1 \mathrm{~m} l$ である（写真 3 , 動物実験に使用した air capsule の外観). 図 1 に示すごとく, air capsule と transsducer と BMT 990 とはチー 


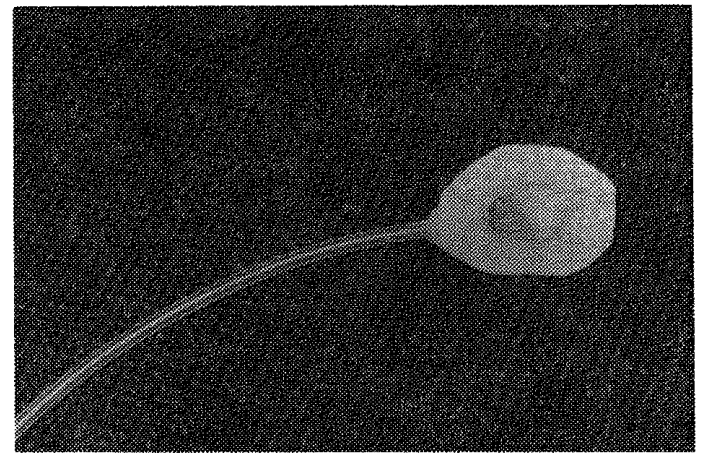

写真 3 air capsule

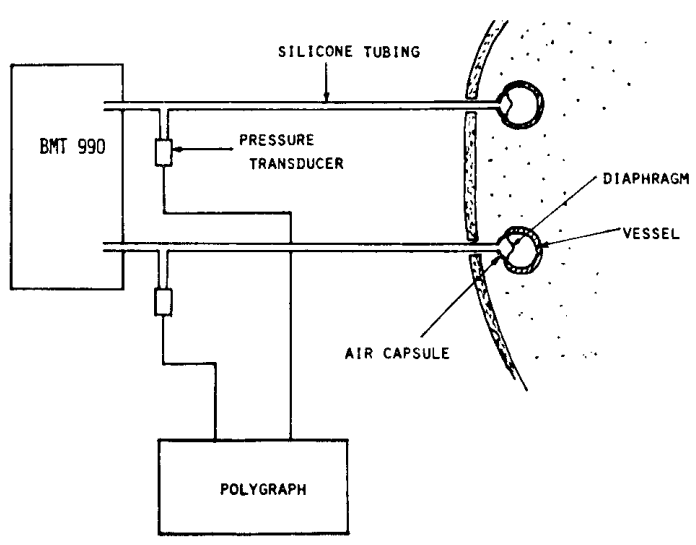

図1 心而圧測定の模式図

ブによって接続してある。

BMT 990 は air capsule で発生した圧変化 を transsducer に伝えるために, 回路内に適量 の空気を送るためのものである。 BMT 990 の 動作は, system volume の position swich を 切り換えることによって開始する。たとえば， $0 \rightarrow 1 ， 0 \rightarrow 2 \cdots \cdots 0 \rightarrow 10$, と10段階に切り換 えることによって vacuum pump と filling pump が作動し，それぞれに応じた数值によっ て空気量が決定される. system volume は心 房圧の圧差が最大になる所で決められ，この時 air capsule は filling pump で送られてきた空 気で自然の状態に膨れている。

以上のようにして capsule に合った position に一度調整するるだけで diaphragm が適度に膨 らみ，心房圧に応じて capsule で受けた圧を transsducer で感知し記録する，また，回路内 から空気もれがある時は capsule がつぶれ測定 值が変って来る．これを防ぐため 7 分毎, 自動 的に system volume が調整される。このよう に一度 air capsule に合った system volume が決められれば，以降自動的に調整が行われ

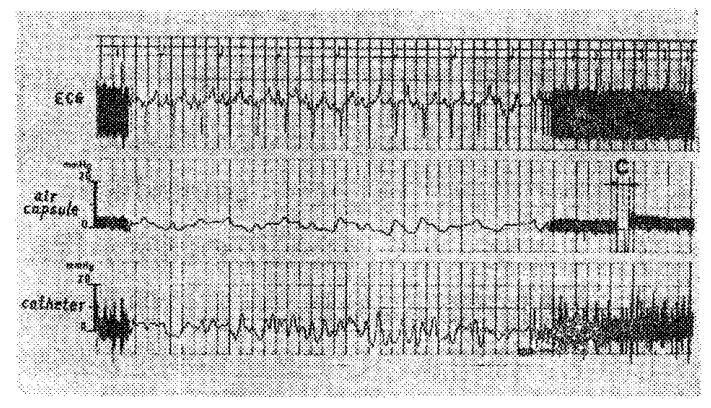

図 2 仔牛に植え込んだ時の心房圧 air capsule では体動の影響がない

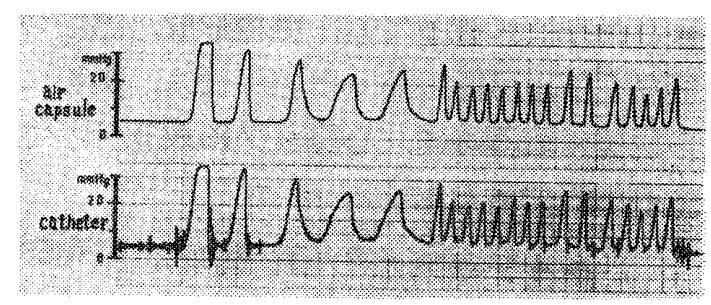

図 3 in vitroで使用した時の各圧波形

万.

\section{実験方法}

犬と仔牛を使用し急性および慢性動物実験を 行った.

体重 $18 \mathrm{~kg}$ の雑種成犬 2 頭を用い気管内挿管 し, 右側開胸にて, 右心耳に air capsule を縫 着また同時に，外頝静脈より右心房にカテーテ ルを挿入し，両者によって右心房圧測定を行い 比較検討した. 犬の場合と同様な方法で仔牛に 取り付け慢性実験による計測比較を行った。

\section{結 果}

これによって得られた波形は，図 2 の通りで ある。ただし， air capsule を心耳に取り付け たために，静脈圧が低くなると心耳が，air capsule を被覆し测定できなくなることがみら れた. (C)は 7 分毎の caliblation が行われてい るところである.

図 3 は, in vitro での air capsule とカテー テルによる直接測定との両者の圧波形を比較し たものである。両者間には，極めて類似した波 形が得られた。 また長期間の使用に対しても air capsule $の$ diaphragm には血栓形成もみ られなかった．カテーテルのように接続部から の液漏れや，チューブ内洗浄による血塊や気泡 が血流中に洗、流される危険性がなかった。 ま た，カテーテルで測定していると transsducer 
医器学 Vol. 49, Suppl. (1979)

の位置を注意しないと水圧によって実際とは違 った圧が出るが，この装置の使用で transsducer の位置を注意する必要がなくなった，その ため，動物の移動に対しても transsducer の位 置を変える必要もなく，心房圧の測定が行える ために，長期の使用に対し，非常に便利であっ た。しかし，問題点として高圧の測定が出来な いことがあげられる。

以上，この BMT 990 を用いて，心房圧を測 定カテーテル直接法と極めて類似した圧波形が 得られ長期間に渡っても，血栓形成，感染の問 題もなく使用可能であった，今後は，実際に人 工心臟植え込み時に，心房カフに取り付けて使 用する計画である。

本研究は文部省科学研究費補助金，昭和53年 度特定研究(2), 肪よび三井物産人工心臟研究費 の援助でおこなわれた。 付 議

\section{東女医大心研外科 和 田 梼 郎}

1）BMT 990 は高い圧では駄目とのことであ
るが圧でいえば限界はどれ位か？

2）心房に取付けたものは有效に作用したとの ことであるがその理由は？

3 ）チューブがシリコン製であることは圧測定 に誤差を生まぬか?

回 答

\section{広島大第 1 外科 田上 重 喜}

1) BMT 990 は最高圧で $50 \mathrm{mmHg}$ まで, 常時 圧にて，をた瞬間的な圧ならば $80 \mathrm{mmHg}$ まで は使用可能である。

2 ）生体の心房に取り付けた場合, air capsule の diaphragm が心耳の壁にあたって測定值が 変る為．実際 diaphargm に血液以外のものが ふれなければカテーテルで測定した值と同じも のが出る。

3 ）この BMT 990 は心房圧用のため, 高くて も $30 \mathrm{cmH}_{2} \mathrm{O}$ 位いしかなく，また圧変化がゆっ くりなために：シリコンチューブでも誤差なく 使用可能である。 